\title{
Corneal epithelial toxicity of antiglaucoma formulations: in vitro study of repeated applications
}

\author{
Marisa Meloni' \\ Giampiero Cattaneo² \\ Barbara De Servi ${ }^{\prime}$ \\ 'VitroScreen In Vitro Research \\ Laboratories, ${ }^{2}$ Thea Farma, \\ Milan, Italy
}

This article was published in the following Dove Press journal:

Clinical Ophthalmology

4 September 2012

Number of times this article has been viewed

Background: By using a biologically relevant and sensitive three-dimensional model of human corneal epithelium and multiple endpoint analysis, assessment of the potential for eye irritation and long-term compatibility of four registered ophthalmological preparations, ie, Timolabak $^{\circledR}$, Timoptol ${ }^{\circledR}$, Nyogel ${ }^{\circledR}$, and Timogel ${ }^{\circledR}$, was performed. This approach enables classification of the potential for irritation, discriminating between mildly irritant and non-irritant ocular substances.

Methods: The exposure protocol included two time periods, ie, 24 hours (acute application) and 72 hours (repeated applications twice daily). This approach allows assessment of not only the acute reaction but also possible recovery, as well as mimicking the potential cumulative effects associated with long-term application. Using benzalkonium chloride (BAK) $0.01 \%$ as a positive control, the following parameters were quantified: cellular viability by MTT test, histological analysis by hematoxylin and eosin staining, passive release of interleukin-1 $\alpha$ by enzyme-linked immunosorbent assay, and OCLN gene expression by quantitative real-time polymerase chain reaction.

Results: Cell viability was reduced to under the $50 \%$ cutoff value after acute exposure ( 24 hours) to BAK $0.01 \%$, and after repeated application ( 72 hours) of Timoptol and Nyogel. Histological analysis after acute exposure showed signs of superficial damage with all formulations, and severe changes after repeated applications of Timoptol, BAK $0.01 \%$, and Nyogel. Timolabak and Timogel did not significantly alter the morphology of the human corneal epithelial cells after the different exposure times. Interleukin- $1 \alpha$ release was greater than that for the negative control ( $>20 \mathrm{pg} / \mathrm{mL}$ ) and the positive control (BAK 0.01\%), Nyogel, and Timoptol treatments and not different after treatment with Timolabak and Timogel. Expression of OCLN, a sign of epithelial barrier impairment, was only significantly upregulated at 24 hours by BAK $0.01 \%$, suggesting a toxic reaction at the ocular surface. OCLN was also overexpressed after repeated application of Nyogel and Timogel.

Conclusion: Overall, the multiple endpoint analysis approach allows classification of these products according to decreasing order of irritation potential as follows: BAK $0.01 \%$, Timoptol, Nyogel, Timogel, and Timolabak.

Keywords: occludin, gene expression, interleukin- $1 \alpha$, eye compatibility, human corneal epithelium

\section{Introduction}

Development of tissue engineering technology for assessment of eye irritation and compatibility has introduced testing strategies which are more predictive in vitro than cell monolayer and even in vivo animal testing. ${ }^{1,2}$ Multiple endpoint analysis, ${ }^{3-5}$ including of $O C L N$ gene expression to evaluate the potential of tear substitutes to cause ocular

Correspondence: Marisa Meloni VitroScreen In Vitro Research Laboratories, 103, Via Mosè Bianchi, 20149 Milan, Italy

Tel +39028907 7608

Email marisa.meloni@vitroscreen.com 
irritation of human corneal epithelium and to limit the use of animal testing in preclinical studies have been published previously. ${ }^{3}$ This proposed approach appears to be suitable for obtaining relevant and predictive preclinical information on the potential ability of a product to interfere with the ocular surface and on the mechanism of toxicity by which a product causes eye irritation after acute and repeated application.

The most innovative modification of multiple endpoint analysis has been the introduction of mRNA expression of occludin (OCLN), a $60 \mathrm{kDa}$ tetraspan membrane protein associated with tight junctions and an early and sensitive biomarker of tight junction functionality, which indicates significant but often neglected superficial signs of early toxicity, and it is relevant when considering treatment of the reactive ocular surfaces found in patients with dry eye. Occludin appears to play a regulatory rather than a structural role in tight junctions, and could be an early marker of physical damage. ${ }^{4,6-10}$

Chemically preserved antiglaucoma formulations can induce ocular surface inflammation after long-term use, as demonstrated by clinical, experimental, and in vitro studies. ${ }^{11-19}$ In particular, benzalkonium chloride (BAK) preservative has been demonstrated to decrease cell viability and enhance apoptotic phenomena and oxidative effects. ${ }^{20}$ Therefore, the experimental model used to evaluate tear substitutes has been adapted specifically to assess multidose ophthalmologic formulations intended for long-term application, ie, for chronic diseases of the eye.

The aim of this study was to assess the potential for eye irritation and long-term compatibility of four registered ophthalmological preparations preserved (Timoptol ${ }^{\circledR}$ and Nyogel $^{\circledR}$ ) or not preserved (Timolabak ${ }^{\circledR}$ and Timogel ${ }^{\circledR}$ ) with BAK, in order to identify early toxic damage to the corneal epithelium, thus helping to predict subclinical reactions at the corneal epithelial level during long-term repeated exposure. The protocol was structured on two time periods (with an additional 6 hours for interleukin- $1 \alpha$ release), ie, 24 hours for acute application and 72 hours for repeated twice-daily application. This approach allows assessment of the acute reaction and possible recovery, thereby mimicking the potential cumulative effects associated with long-term application. The following parameters were quantified using BAK $0.01 \%$ as the positive control: cell viability, using a modified 3-(4,5-dimethylthiazol-2-yl)-2,5diphenyltetrazolium bromide (MTT) test; histological analysis using hematoxylin and eosin (Merck, Darmstadt, Germany) staining; passive interleukin-1 $\alpha$ release by enzyme-linked immunosorbent assay; and OCLN expression by quantitative real-time polymerase chain reaction (PCR).

\section{Materials and methods Biological model}

The reconstructed human corneal epithelium model supplied by SkinEthic ${ }^{\circledR}$ Laboratories (Nice, France) consisted of immortalized human corneal epithelial cells cultured on an inert permeable polycarbonate $0.5 \mathrm{~cm}^{2}$ filter for 5 days at the air-liquid interface in a supplemented chemically defined medium (modified MCDB 153). ${ }^{21,22}$ The morphology of the human corneal epithelial model is similar to that of human corneal epithelium, with a flattened layer of superficial non-keratinized cells. ${ }^{4}$ The resulting three-dimensional construct shows the morphology of the stratified cellular organization of human corneal epithelium, and has been characterized for the different relevant markers. ${ }^{1}$ Human corneal epithelial cells were shipped on day 5. Upon arrival, they were placed in a 6-well culture plate (BD Falcon ${ }^{\mathrm{TM}}$ ) with $1 \mathrm{~mL}$ of chemically defined maintenance medium supplied by SkinEthic, which was changed every 24 hours. Different batches of human corneal epithelial cells were used, with an average thickness of $70 \mu \mathrm{m}$.

\section{Products, controls, and treatments}

The products tested correspond to those used routinely in the long-term treatment of glaucoma and contain timolol from $0.1 \%$ (Timogel and Nyogel) to $0.5 \%$ (Timolabak and Timoptol) as the active ingredient. Timogel and Timolabak are preservative-free and Nyogel and Timoptol contain BAK as a chemical preservative (Table 1).

Saline solution was used as the negative control because of its neutral effect on the epithelial surface. The reference standard, BAK, was used as a positive control at $0.01 \%$ (a non-toxic dose, as confirmed by the MTT test after 24 hours of exposure from our internal data). Next, $30 \mu \mathrm{L}$ of the test items were applied directly and gently spread over the

Table I Positive and negative controls and identification of ophthalmological formulations

\begin{tabular}{lll}
\hline Identification code & Active ingredient & Preservation system \\
\hline Negative control & $\mathrm{NaCl} 0.9 \%$ & Sterile \\
Positive control BAK & Benzalkonium chloride & BAK 0.01\% \\
Timogel $0.1 \%$ & Timolol maleate & - \\
Nyogel $0.1 \%$ & Timolol maleate & BAK \\
Timolabak $0.5 \%$ & Timolol maleate & - \\
Timoptol $0.5 \%$ & Timolol maleate & BAK \\
\hline
\end{tabular}


entire epithelial surface. Duplicate tissues were used for the MTT assay, interleukin- $1 \alpha$ quantification, the gene expression study, and single tissue for histology with the following treatment procedures:

- $\operatorname{six}$ hours of exposure exclusively for interleukin- $1 \alpha$ release

- 24 hours of acute application followed by a gentle saline wash, ie, standard exposure, for in vitro toxicological study of human corneal epithelial cell models

- 72 hours of twice-daily exposure to evaluate cumulative effects, with a saline wash performed at the end of the experiment.

\section{MTT test}

The Mossman ${ }^{23}$ test was performed on a duplicate sample of human corneal epithelial cells at the end of the exposure time, whereby the cells were rinsed with saline solution and transferred to plates containing $300 \mu \mathrm{L}$ of MTT solution (diluted to $0.5 \mathrm{mg} / \mathrm{mL}$ in maintenance medium). After 3 hours of incubation at $37^{\circ} \mathrm{C}$, the human corneal epithelial cells were placed at room temperature in isopropanol for extraction of formazan crystals, and optical density was measured at $570 \mathrm{~nm}$ (Microplate Autoreader Infinite ${ }^{\circledR}$ M-200, Tecan, Durham, NC). The results are expressed as percentages of viability compared with negative controls. The accuracy of the measurements ranged from an optical density of 0 to 2 .

\section{Enzyme-linked immunosorbent assay}

The medium of the HCE was collected immediately after the specified incubation time and frozen at $-20^{\circ} \mathrm{C}$ until needed for enzyme-linked immunosorbent assay. Interleukin- $1 \alpha$ release was quantified in $200 \mu \mathrm{L}$ of human corneal epithelial cell medium using an enzyme-linked immunosorbent assay (Kit Quantikine ${ }^{\circledR}$ DLA 50 IL-1, R\&D Systems, Milan, Italy). Optical density was measured at $450 \mathrm{~nm}$, and the results are expressed in $\mathrm{pg} / \mathrm{mL}$.

\section{Histology}

At the end of the experiments, the human corneal epithelial cells were fixed in 10\% formalin solution (Sigma, St Louis, MO). After embedding in paraffin, sections $4 \mu \mathrm{m}$ in thickness were cut, and hematoxylin and eosin staining was performed. The histological samples were analyzed under a light microscope. The overall morphology and any changes were analyzed and compared with the negative controls.

\section{Transcriptional study of occludin mRNA using quantitative real-time PCR}

Total RNA was extracted from the human corneal epithelial cells using an RNAqueous kit (Ambion ${ }^{\circledR}$, Applied Biosystems, Monza, Italy) according to the manufacturer's protocol. Next, $2 \mu \mathrm{g}$ of RNA was reverse-transcribed in a $20 \mu \mathrm{L}$ reaction using a high-capacity cDNA reverse transcription kit (Applied Biosystems) in a thermal cycler (Applied Biosystems ABI Prism 7500 real-time PCR system) under the following conditions: $25^{\circ} \mathrm{C}$ for 10 minutes, $37^{\circ} \mathrm{C}$ for 60 minutes, and $85^{\circ} \mathrm{C}$ for 5 seconds. Real-time reverse transcriptase PCR was performed in triplicate using the Taqman method in a $25 \mu \mathrm{L}$ volume with the ABI Prism 7500 real-time PCR system instrument (Applied Biosystems). cDNA was amplified using the TaqMan Universal PCR Master Mix and TaqMan gene expression assay (human occludin: Taqman probe OCLN Hs00170162_m1 and human GAPDH, as the calibrator gene: Taqman probe GAPDH Hs99999905_m1). The thermal cycling conditions were $95^{\circ} \mathrm{C}$ for 10 minutes followed by 40 amplification cycles $\left(95^{\circ} \mathrm{C}\right.$ for 15 seconds and $60^{\circ} \mathrm{C}$ for one minute). Relative quantification was determined upon a $95 \%$ specified relative quantification minimummaximum confidence setting. The relative quantification was determined using the equation (1):

$$
2^{-\left(\Delta \Delta \mathrm{C}_{\mathrm{T}}\right)} \text { where } \Delta \Delta \mathrm{C}_{\mathrm{T}}=\Delta \mathrm{C}_{\mathrm{T} \text { sample }}-\Delta \mathrm{C}_{\mathrm{T} \text { calibrator }}
$$

Calculations of relative gene expression used relative differences in the threshold cycle, $\mathrm{C}_{\mathrm{T}}$, (ie, the cycle of PCR at which fluorescence reaches a given value or threshold in the log-linear range of amplification). The $\mathrm{C}_{\mathrm{T}}$ at which PCR amplification took place for a particular threshold value in the exponential phase was determined using sequence detector software.

The relative quantification is the fold-change compared with the calibrator (eg, untreated sample, time zero). The calibrator has a relative quantification value of 1 . All samples are compared with the calibrator. Relative quantification is significant when there is a minimum two-fold change, ie, a relative quantification $>2$ or $<0.5$. This is within the variation allowed for the technique. The relative quantification data are shown as the mean \pm standard deviation. The software set a confidence level at $95 \%$ for a real range of biological significance.

\section{Results}

\section{Cell viability measured by MTT test}

As expected, BAK induced a dose-dependent and protocoldependent decrease in cell viability (Figure 1). BAK $0.01 \%$ 
PS $22-09-$ MTT test

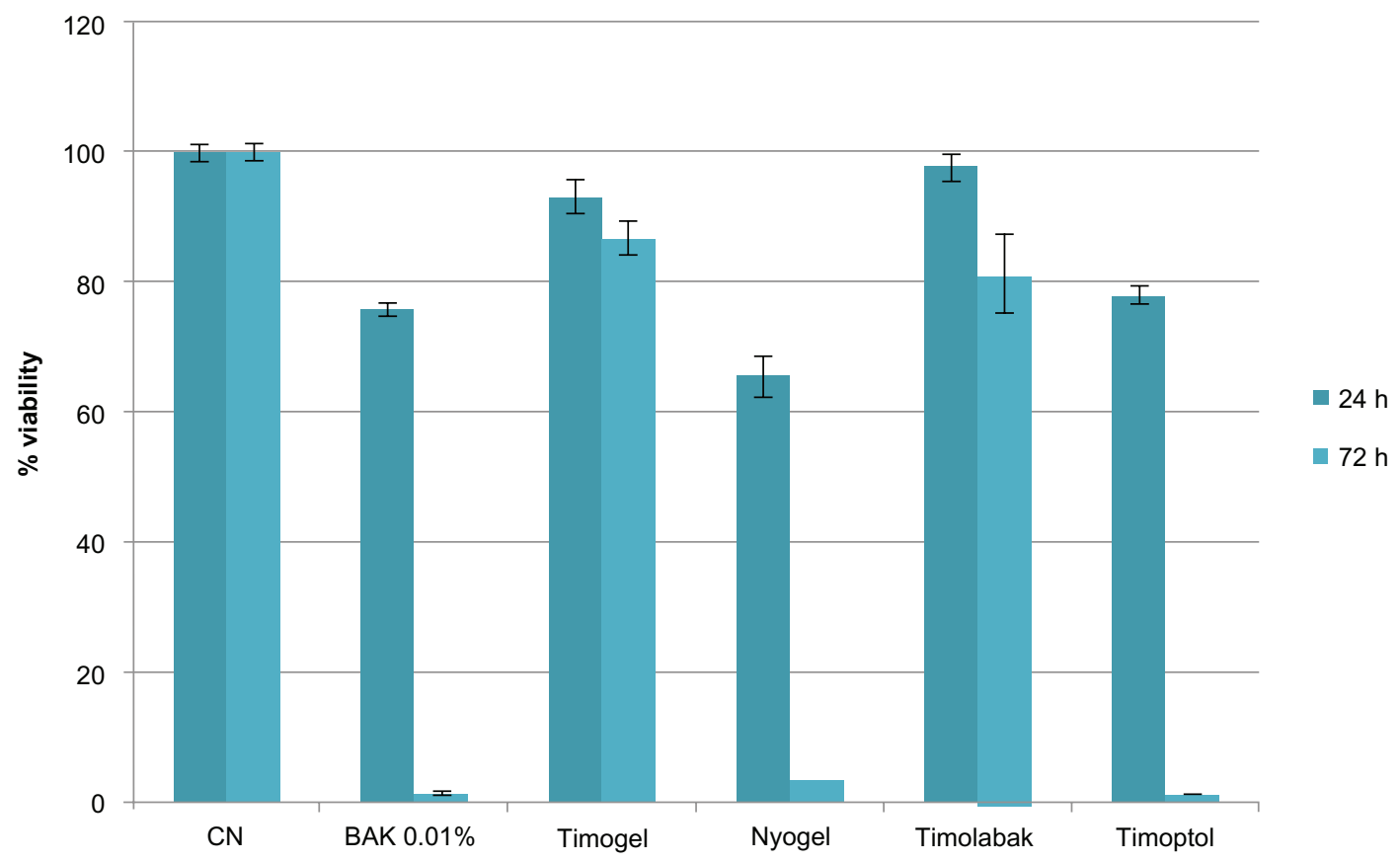

Figure I Cellular viability measured by the MTT test after treatment of the three-dimensional human corneal epithelium with CN, BAK 0.0I\% and Timogel, Nyogel, Timolabak, Timoptol for 24 hours and 72 hours.

Note: Errors bars indicate standard deviations.

Abbreviations: CN, saline control solution; BAK, benzalkonium chloride; MTT, 3-(4,5-dimethylthiazol-2-yl)-2,5-diphenyltetrazolium bromide.

was found to be non-toxic after acute application for 24 hours, but was seen to be severely toxic after 72 hours of repeated application. Using a cut-off value of $50 \%$ viability to discriminate between irritation and nonirritation after 24 hours of exposure, all the products could be classified as not irritating to the eye. However, Nyogel had a residual viability of $65.63 \%$, therefore was better classified as borderline. Repeated application over 72 hours enabled differentiation between the products, with only Timogel and Timolabak not reducing cell viability to less than $50 \%$. In contrast, after 72 hours of exposure, Nyogel, Timoptol, and BAK 0.01\% markedly decreased cell viability to less than $10 \%$.

\section{Release of interleukin-I $\alpha$}

Untreated tissues were used as controls, and interleukin-1 $\alpha$ release $>20 \mathrm{pg} / \mathrm{mL}$ was considered to be significant. Treatment with BAK $0.01 \%$ induced significant interleukin- $1 \alpha$ release starting at 6 hours $(60 \mathrm{pg} / \mathrm{mL})$, continuing through to 72 hours of treatment ( $140 \mathrm{pg} / \mathrm{mL}$, Figure 2). This behavior reflected inflammation and confirmed the well known potential of the molecule to cause eye irritation. Treatment with Nyogel was associated with lower but significant release of interleukin- $1 \alpha$ compared with the positive BAK control. Maximum interleukin- $1 \alpha$ release of $140 \mathrm{pg} / \mathrm{mL}$ was observed for Nyogel after 72 hours of exposure (Figure 2). Interleukin-1 $\alpha$ release values for Timoptol were moderately low, but were significantly different from the control mean of $40 \mathrm{pg} / \mathrm{mL}$. Timogel and Timolabak did not induce significant interleukin- $1 \alpha$ during acute or longer term exposure (Figure 2).

\section{Histological analysis}

Figure 3 shows the overall morphology of the human corneal epithelial cells after treatment. After acute exposure for 24 hours, many signs of superficial damage were detected for all the products. Severe changes and tissue necrosis were observed after 72 hours for Timoptol, BAK 0.01\%, and Nyogel. Timolabak and Timogel did not induce significant changes in human corneal epithelial cell morphology. The morphological results were consistent with those for cell viability.

\section{Transcriptional study of occludin mRNA using quantitative real-time PCR}

This study monitored the response of the OCLN gene at the transcriptional level after exposure to the different test products. It is important to note that the response described after acute exposure for 24 hours and after repeated exposure for 72 hours refers to a dynamic pathway and not to an endpoint (Figure 4). 


\section{IL-1 ALPHA release}

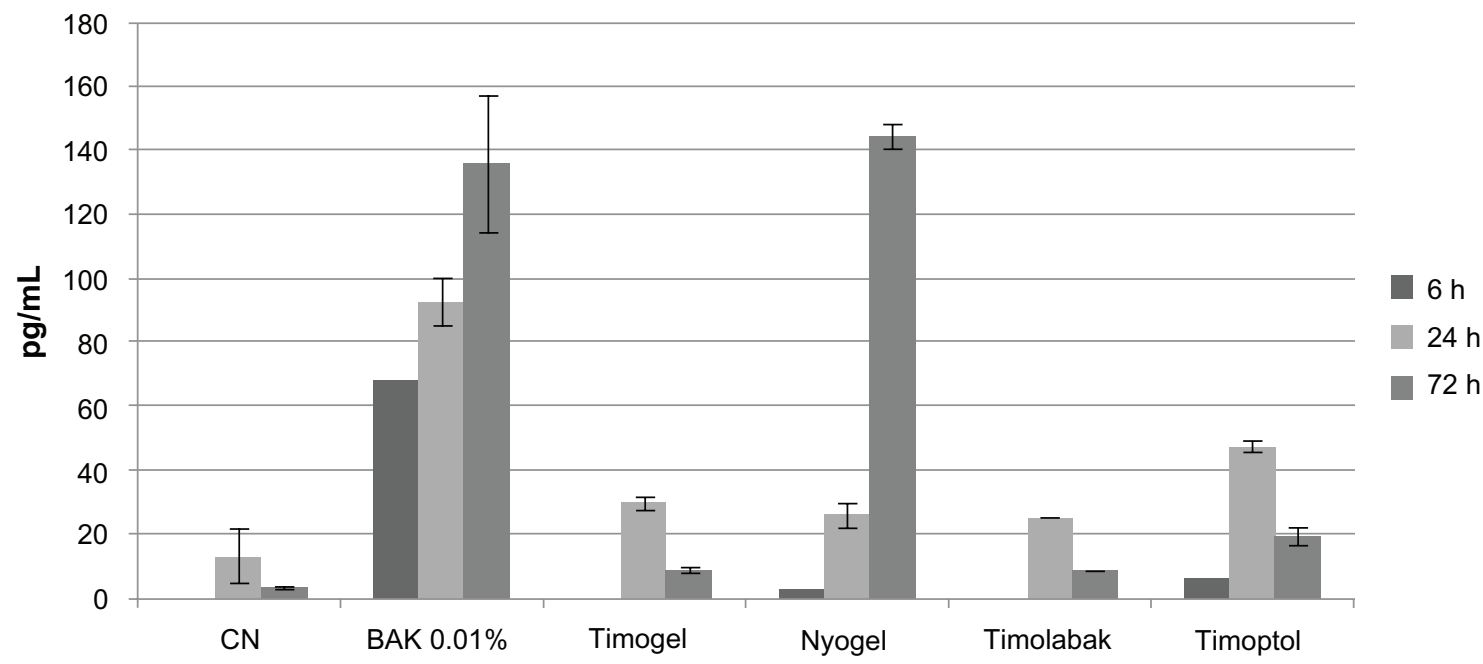

Figure 2 Enzyme-linked immunosorbent assay quantification of interleukin- $1 \alpha$ release in the culture media after different exposures (6, 24 , and 72 hours) to BAK $0.01 \%$ and test items compared with control (saline solution) values.

Abbreviations: $\mathrm{CN}$, saline control solution; BAK, benzalkonium chloride; IL- $\alpha$, interleukin-I $\alpha$.

Because occludin has a functional role in response to modifications occurring at the tight junction level, occludin transcription can be interpreted as a toxicity pathway indicating damage, neutral activity or potential recovery. As reported previously, ${ }^{4}$ downregulation of $O C L N$ (relative quantification $<0.5$ ) after 24 hours of acute exposure was directly associated with damage, whereas upregulation (relative quantification $>2$ ) at this time was associated with a positive defense mechanism for restoring the epithelial integrity damaged by exposure. Repeated exposure over

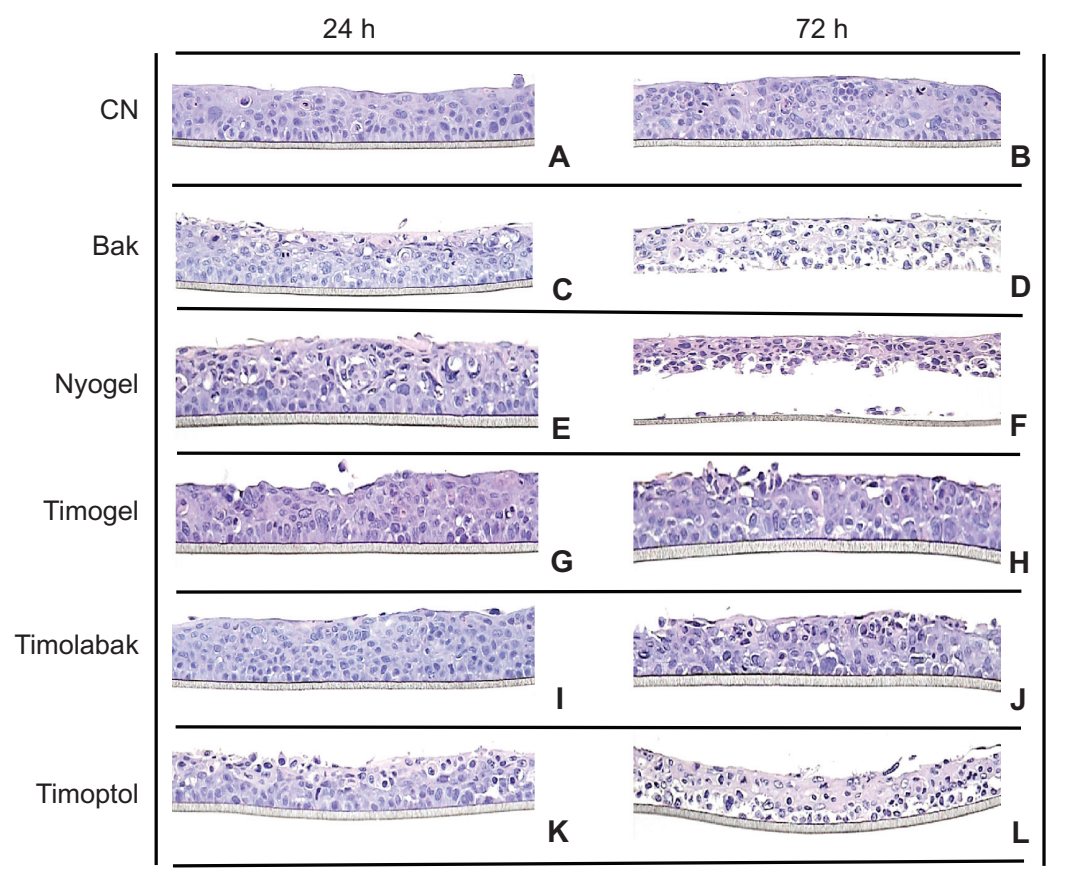

Figure 3 Histomorphological analysis of three-dimensional human corneal epithelium after 24 hours and 72 hours of treatment with saline, BAK $0.01 \%$, and test items. Normal human corneal epithelium morphology was observed with the saline solution (A and B), ie, a layer of nonkeratinized and flattened superficial cells, and an intermediate cell layer with cells displaying lateral cytoplasmic extension similar to wing cells and a basal layer with regular column cuboidal cells. After 24 hours of treatment, BAK $0.01 \%$ modified the continuity of the superficial film morphology with the appearance of few necrotic cells and a reduced thickness compared with the control (C). The morphology after repeated application of BAK $0.01 \%$ for 72 hours was severely damaged, with tissue necrosis observed in basal cells that were still attached to the polycarbonate filter (D). Nyogel (E and $\mathbf{F})$, Timogel ( $\mathbf{G}$ and $\mathbf{H})$, Timolabak (I and J), and Timoptol (K and $\mathbf{L})$.

Note: Magnification 20x. 


\section{OCLN gene expression}

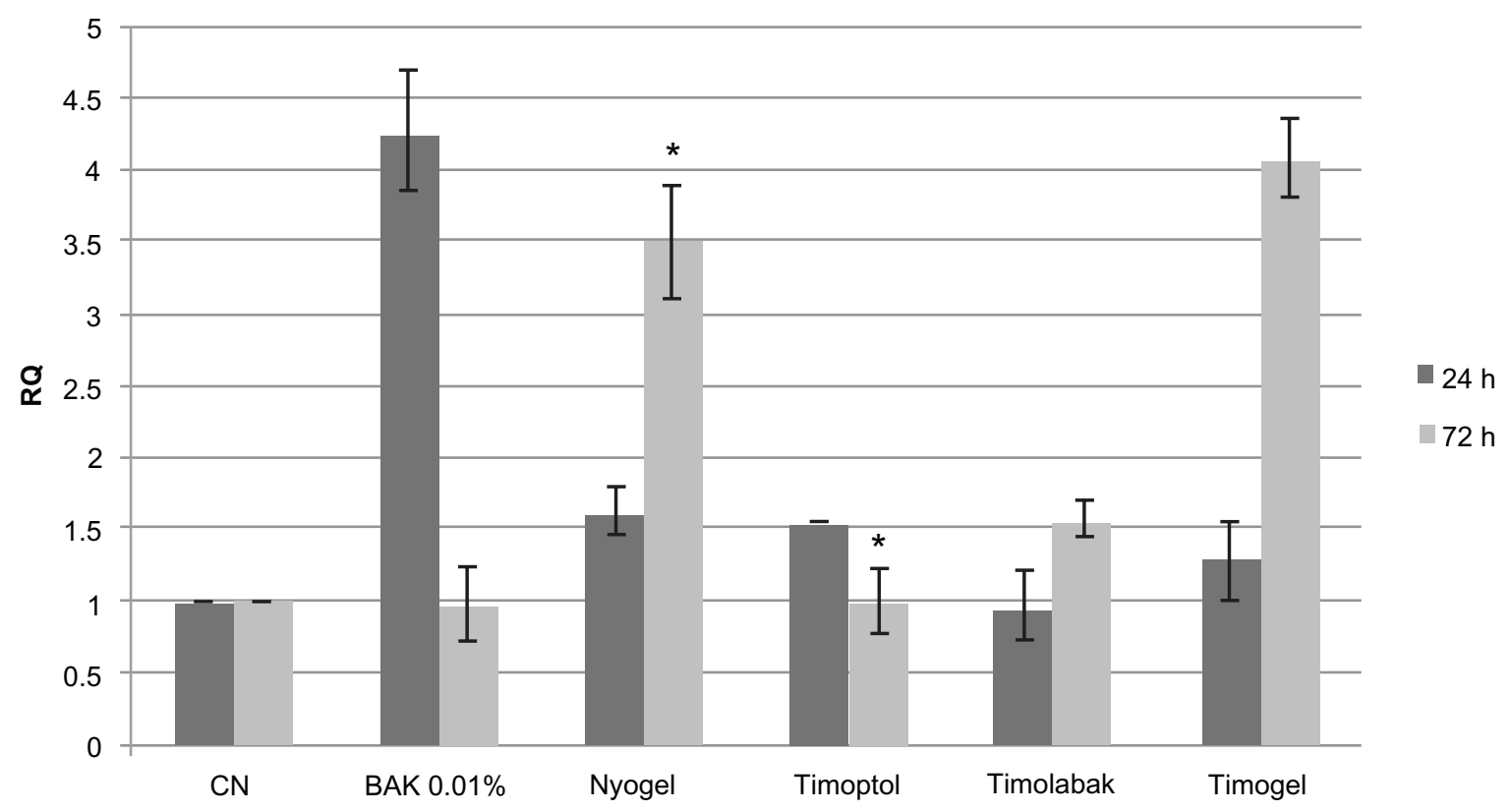

Figure 4 Quantitative analysis of occludin mRNA expression by quantitative real-time polymerase chain reaction (Taqman assay) in the control nontreated human corneal epithelium and the human corneal epithelium treated with the study products and $0.01 \%$ benzalkonium chloride solutions after acute ( 24 hours) and repeated application ( 72 hours).

Notes: The untreated control for each time point was used as a calibrator. A two-fold change of RQ is considered significant in comparison with the calibrator: RQ of $>2$ or $<0.5 . R Q_{\min }$ and $R Q_{\max }=$ range of possible $R Q$ values defined by the standard error of the delta Ct. Confidence interval set at $95 \%$.

Note: *Not relevant data due to the cell viability results.

Abbreviations: $\mathrm{RQ}$, relative quantification; $\mathrm{CN}$, saline control solution.

72 hours can induce reversible or irreversible damage, and in the event of irreversible toxic damage, downregulation or no regulation of the gene may be seen. When reversible damage occurs, the $O C L N$ gene is upregulated. Overexpression of $O C L N$ after acute exposure for 24 hours indicated an interaction with the corneal structure, corresponding to epithelial damage. Thereafter, the $O C L N$ gene became significantly overexpressed (relative quantification $>2$ ) on exposure to BAK $0.01 \%$, indicating a role for the occludin protein at the tight junction level. This behavior clearly suggests a defense mechanism against toxicity which was not detected by the MTT test. Timoptol and Nyogel containing BAK as a preservative system showed similar results (relative quantification 1.5), with no significant change in $O C L N$ expression. Timolabak did not have any effect on tight junction structure, indicating neutral nontoxic activity (Figure 4).

Repeated exposure to the product for 72 hours allowed us to glean information on the degree of reversible or irreversible damage to the corneal epithelial structure. Nyogel and Timogel both induced significant overexpression of OCLN (relative quantification $>3.5$ and 4.0, respectively), indicating a reversible mechanism (Figure 4). These results are related mainly to the physical formulation and its film-forming properties, indicating a stronger interaction with the epithelial surface as compared with the liquid formulation. The results for Timoptol and Nyogel at 72 hours cannot be correctly interpreted because of the appearance of tissue necrosis and damage at the mRNA level. Timolabak did not modify the tight junction structure, showing neutral activity and suggesting a nontoxic interaction. Thus, dynamic monitoring of OCLN gene expression is important for being able to determine if interaction between the product and the cornea occurs with or without damage to the epithelium surface, enabling a deeper understanding of the extent of its toxic action, with or without tissue recovery after repeated doses.

\section{Discussion}

The present study investigated the potential for irritation and cumulative toxicity after repeated application of four ophthalmological antiglaucoma preparations containing timolol, ie, Timoptol, Nyogel, Timogel, and Timolabak compared with the well known preservative BAK at $0.01 \%$ using an in vitro model of reconstructed human corneal epithelium.

Using a modified protocol for multiple endpoint analysis that included mRNA expression of occludin, it was possible to assess not only the acute reaction but also to mimic the potential cumulative effects of long-term use at the level of the epithelium. All the parameters of multiple endpoint 
analysis support classification of the products according to their irritation potential, in decreasing order as follows: BAK $0.01 \%$, Timoptol, Nyogel, Timogel, and Timolabak.

Cell viability measured at the basal level of the human corneal epithelium using the MTT test method decreased to below the $50 \%$ cutoff level after repeated applications of BAK $0.01 \%$, Nyogel, and Timoptol for 72 hours. Timolabak and Timogel did not decrease cell viability to less than $50 \%$ after repeated exposure. Both interleukin- $1 \alpha$ release and morphological analysis were consistent with the viability results. The $O C L N$ gene after 24 hours was significantly overexpressed (relative quantification $>2$ ) only after exposure to BAK $0.01 \%$, reflecting the role of the occludin protein at the tight junction level, and this behavior clearly suggests a defense mechanism against barrier impairment, a toxic reaction that was not detected by the MTT test.

The 72-hour results enable discrimination between products having a neutral effect on the surface of the corneal epithelium that do not induce $O C L N$ expression (Timolabak) and those allowing recovery of barrier function (Timogel). Thus, the modified multiple endpoint analysis used in this study is a valuable and promising tool for in vitro assessment of eye irritation, with the power to detect mildly irritant products and those with potential to cause subclinical eye irritation as opposed to severe eye irritation.

Early prediction of subclinical reactions induced by longterm treatment represents a great advantage in the prevention of acute side effects, and the discomfort of chronic inflammatory diseases, such as dry eye. The experimental model proposed with multiple endpoint analysis is a new tool that could be of help both during product development and for clinicians in order to have predictive and sensitive information about compliance with personalized treatments for glaucoma.

\section{Disclosure}

The authors report no conflicts of interest in this work.

\section{References}

1. Doucet O, Lanvin M, Thillou C, et al. Reconstituted human corneal epithelium: a new alternative to the Draize eye test for the assessment of the eye irritation potential of chemicals and cosmetic products. Toxicol In Vitro. 2006;20:499-512.

2. Van Goethem F, Adriaens E, Alepee N, et al. Prevalidation of a new in vitro reconstituted human cornea model to assess the eye irritating potential of chemicals. Toxicol In Vitro. 2006;20:1-17.

3. Pauly A, Meloni M, Brignole-Baudouin F, Warnet JM, Baudouin C. Multiple endpoint analysis of the 3D-reconstituted corneal epithelium after treatment with benzalkonium chloride: early detection of toxic damage. Invest Ophthalmol Vis Sci. 2009;50:1644-1652.

4. Meloni M, Pauly A, De Servi B, Le Varlet B, Baudouin C. Occludin gene expression as an early in vitro sign for mild eye irritation assessment. Toxicol In Vitro. 2010;24:276-285.
5. Meloni M, Dalla Valle P, Cappadoro M, De Wever B. The importance of multiple endpoint analysis (MEA) using reconstituted human tissue models for irritation and biocompatibility assay. Invitox Abstract Book. 2002:4-7.

6. McCarthy KM, Skare IB, Stankewich MC, et al. Occludin is a functional component of the tight junction. J Cell Sci. 1996;109(Pt 9): 2287-2298.

7. Matter K, Balda MS. Epithelial tight junctions, gene expression and nucleo-junctional interplay. J Cell Sci. 2007;120(Pt 9):1505-1511.

8. Schneeberger EE, Lynch RD. The tight junction: a multifunctional complex. Am J Physiol Cell Physiol. 2004;286:C1213-C1128.

9. Ajani G, Sato N, Mack JA, Maytin EV. Cellular responses to disruption of the permeability barrier in a three-dimensional organotypic epidermal model. Exp Cell Res. 2007;313:3005-3015.

10. Ban Y, Cooper LJ, Fullwood NJ, et al. Comparison of ultrastructure, tight junction-related protein expression and barrier function of human corneal epithelial cells cultivated on amniotic membrane with and without air-lifting. Exp Eye Res. 2003;76:735-743.

11. Baudouin $\mathrm{C}$, Hamard $\mathrm{P}$, Liang $\mathrm{H}$, et al. Conjunctival epithelial cell expression of interleukins and inflammatory markers in glaucoma patients treated over the long term. Ophthalmology. 2004;111: 2186-2192.

12. Terai N, Müller-Holz M, Spoerl E, Pillunat LE. Short-term effect of topical antiglaucoma medication on tear-film stability, tear secretion, and corneal sensitivity in healthy subjects. Clin Ophthalmol. 2011;5: 517-525.

13. Inoue K, Fujimoto T, Higa R, et al. Efficacy and safety of a switch to latanoprost $0.005 \%$ + timolol maleate $0.5 \%$ fixed combination eyedrops from latanoprost $0.005 \%$ monotherapy. Clin Ophthalmol. 2012;6: 771-775.

14. Costa VP, Moreira H, Paolera MD, de Moraes Silva MRB. Efficacy and safety of travoprost $0.004 \%$ /timolol $0.5 \%$ fixed combination as transition therapy in patients previously on prostaglandin analog monotherapy. Clin Ophthalmol. 2012;6:699-706.

15. Nakakura S, Tabuchi H, Baba Y, et al. Comparison of the latanoprost $0.005 \%$ /timolol $0.5 \%+$ brinzolamide $1 \%$ versus dorzolamide $1 \%$ / timolol $0.5 \%$ + latanoprost $0.005 \%$ : a 12 -week, randomized open-label trial. Clin Ophthalmol. 2012;6:369-375.

16. Inoue K, Setogawa A, Higa R, Moriyama R, Wakakura M, Tomita G. Ocular hypotensive effect and safety of travoprost $0.004 \% /$ timolol maleate $0.5 \%$ fixed combination after change of treatment regimen from ß-blockers and prostaglandin analogs. Clin Ophthalmol. 2012;6: 231-235.

17. Gado AS, Macky TA. First experience with BAK-free travoprost $0.004 \%$ in topical glaucoma medication. Clin Ophthalmol. 2012;6:1-4.

18. Hommer A, Kimmich F. Switching patients from preserved prostaglandin-analog monotherapy to preservative-free tafluprost. Clin Ophthalmol. 2011;5:623-631.

19. Wirta D, VanDenburgh A, Weng E, Whitcup S, Kurstjens S, Beddingfield F. Long-term safety evaluation of bimatoprost ophthalmic solution $0.03 \%$ : a pooled analysis of six double-masked, randomized, active-controlled clinical trials. Clin Ophthalmol. 2011;5: 759-765.

20. De Saint Jean M, Brignole F, Bringuier AF, et al. Effects of benzalkonium chloride on growth and survival of Chang conjunctival cells. Invest Ophthalmol Vis Sci. 1999;40:619-630.

21. Nguyen DH, Beuerman RW, DeWever B, Rosdy M. Three dimensional construct of the human corneal epithelium for in vitro toxicology. In: Salem H, Katz S. Alternative Toxicology Methods. Boca Raton, FL: CRC Press; 2003.

22. Powers MJ, Amenuvor L, Rodin R, Darner J. An in vitro human corneal epithelial model for evaluation of ocular response to xenobiotic compounds. Invest Ophthalmol Vis Sci. 2007;48:Abstr 790.

23. Mossman T. Rapid colorimetric assay for cell growth and survivalapplication to proliferation and cytotoxicity assays. J Immunol Methods. $1983 ; 65: 55-63$. 


\section{Publish your work in this journal}

Clinical Ophthalmology is an international, peer-reviewed journal covering all subspecialties within ophthalmology. Key topics include: Optometry; Visual science; Pharmacology and drug therapy in eye diseases; Basic Sciences; Primary and Secondary eye care; Patient Safety and Quality of Care Improvements. This journal is indexed on
PubMed Central and CAS, and is the official journal of The Society of Clinical Ophthalmology (SCO). The manuscript management system is completely online and includes a very quick and fair peer-review system, which is all easy to use. Visit http://www.dovepress.com/ testimonials.php to read real quotes from published authors. 